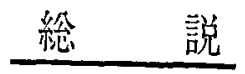

\title{
微粒子爫磁性
}

船渡川善哉*, 山洞 富 代**

\section{-1. 序論}

微粒子の持つ物性の中で最も興味深いものの一つは， 強磁性粒子の抗磁力である。たとへば，純鉄の抗磁力は， わすか $0.05 \mathrm{Oe}$ であるがその結晶を何んらかの方法で 小さくして行くと, 図1亿示すように抗磁力が增加し数 万倍の值か観察される.

粒子径を小さくすると抗磁力が增すと言う現象は古く 汃ら知られていたが，ての抗磁力か注目されたのはその よって来る原因が理論的に明らかになってからであっ た.

その後、磁石材料としての応用の面からもさかんな研 究が行なわれ，数多くの成果が生まれた。順を追ってそ れらを紹介しょう。

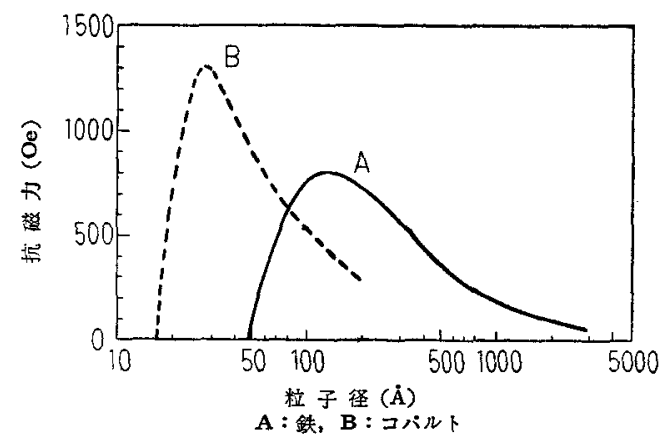

図 1 粒子径と抗磁力1

\section{2. 磁 区 理 論}

強磁性体は一般に，多くの磁区之呼ばれる領域から成 り立っている．それらの磁区構造を決める因子として， 静磁エネルギーと磁壁のエネルギーがあって，両者の和 が最小になるような磁区配列をしている。静磁エネルギ 一は磁極が表われるために生ずるエネルギーで，大きな 結晶ではこのエネルキーが磁区エネルギーに最も大きく 寄与するため，磁極方婊われないような磁区構造をとっ ている.一方, 結晶をだんだん小さくして行くと, 磁堲 のエネルギーが相対的に大きくなり，磁極が表れて引磁 壁のない状態がニネルギー的に好ましくなり，ある粒子 径以下で単一磁区が金現する・すなわち粒子自体がーつ の磁石になっている(図 2).C. Kittel ${ }^{2)}$ に上机ば，こ の臨界半径 $R_{c}$ は，次式で示される。ここで $\sigma_{w}$ は単位

*横浜国立大学（神奈川県横浜市南区大凮町）

**京三製作所（横浜市豍見区平安町）
面積当りの磁壁のエネルキー, $I_{s}$ 汁飽和磁化である.

$$
R_{c}=9 \sigma_{w w} / 4 \pi I_{s}{ }^{2}
$$

鉄についてての $R_{c}$ を計算すると, 約 $70 \AA$ の值になる. 次にてのような単一磁区粒子の抗磁力について考党てみ 上う.

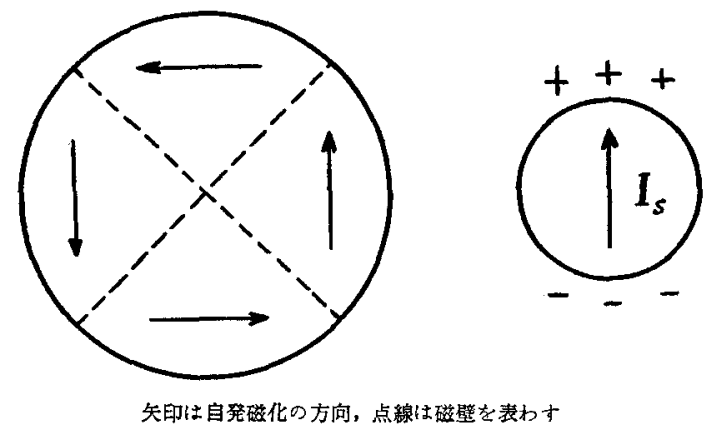

図 2 微粒子の磁区模型

一般に強磁性体の磁化反転は，磁壁移動によ。て行な われるため，抗磁力は磁壁の動きやすさによって決まっ てしまう。すなわち，焼き入れなどの操作により，結晶 内部にひずみを与えて磁壁を動きにくくすると抗磁力が 增す。一方，単一磁区になると，磁化反転はスピンの回 転によって行なわれるため，もし結晶内部に異方性があ るとそのエネルギーに打ち勝つ外部エネルギーをあたえ なければ，磁化の反転は行なわ礼子い，てのため微粒子 が非常に大きな抗磁力を示すのである．この異方性とし

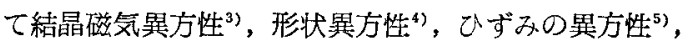
交换異方性 ${ }^{6}$ 名提案されている。

結晶磁気異方性 $K_{1}$ 亿よる抗磁力 $H_{c}$ 浊， $I_{s}$ を飽和 磁化とすると，次式で示される。

$$
H_{c}=2 K_{1} / I_{s} \text {. }
$$

形状異方性汇よる抗磁力は $N_{0}$ を長軸の, Nt を短軸 の反磁場係数とすると

$$
H_{c}=\left(N t-N_{0}\right) I_{s} .
$$

長軸が短軸に比べて著しく長い場合 $N_{0}=0, N t=2 \pi$ で あり, ての時の抗磁力は

$$
H_{c}=2 \pi I_{s}=B_{s} / 2 \text {. }
$$

$B_{s}$ 注飽和磁気 $4 \pi I_{s}$ である.

異方的な内部ひずみによって生じた内部応力を $T$ と すると

$$
H_{c}=3 \lambda T / I_{s} .
$$

入 は等方磁ひずみ．とれらの里方性による抗磁力を鉄， 
ニッケル,コバルトに対して計算した結果を表 1 亿示し た。

表 1 単一磁区の抗磁力2

\begin{tabular}{l|r|r|r}
\hline & $2 K_{1} / I_{s}$ & $2 \pi I_{s}$ & $3 \lambda T / I_{s}$ \\
\hline $\mathrm{Fe}$ & 500 & 10,700 & 600 \\
$\mathrm{Ni}$ & 135 & 3,150 & 4,000 \\
$\mathrm{Co}$ & 6,000 & 8,800 & 600 \\
\hline
\end{tabular}

単位: Oe, $T=2 \times 10^{10} \mathrm{dyne} / \mathrm{cm}^{2}$ とたた。

交換異方性は 1956 年 Meiklejohn, Bean により発見 された，すなわちコバルト微粒子を酸化させ，表面に反 強磁性酸化コバルトを作り，その Néel 点より高い温度 から磁場中冷却を施すと，一方向き異方性を生ずる。そ の異方性を $K u$ とすると抗磁力は

$$
H_{c}=\left(K u / I_{s}\right)+\left(2 K_{1} / I_{s}\right)
$$

と表わされ，磁化曲線の原点が $K u / I_{s}$ だけずれる。す なわちある向きのみか磁化しやすく，反面抗磁力，残留 斑気が大きと言う今までにない磁石の概念を作った。

\section{3. 微粒子磁石}

微粒子磁石には結晶磁気異方性を利用したバリウムフ エライト，マンガンビスマス，マンガンアルミ，形状異 方性を利用した鉄，コバルト微粒子磁石などがある。

\section{1 バリウムフェライト}

強磁性を示す $\mathrm{BaO} \cdot 6 \mathrm{Fe}_{2} \mathrm{O}_{3}$ は 1952 年 Went ら"に よって初めて詳細なる報告が出された。残留磁気 $B_{\boldsymbol{r}}=$ $2,050 \mathrm{~g}, B$-抗磁力 ${ }_{B} H_{C}=1,450 \mathrm{Oe}$ ，工ネルギ一積の最 大值 $(B \cdot H)_{\max }=0.85 \times 10^{6} \mathrm{~g}$.Oe の磁性を持ち，結晶 磁気異方性が大きく，飽和磁気が小さいので，(2) 式で 計算される $H_{c}$ は $17,000 \mathrm{Oe}$ と非常に大きい，実験的

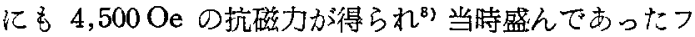
エライト研究に，さらに大きな関心孛呼び起した。

引き続いて Rathenau ら"とよって，磁場中成型の效 果が見いだきれた，てれは，バリウムフエライトを縮 成型するときに磁場を加えると，粒子がその方向にるる い，焼結後もその状態が保たれ，残留磁気か㵔しく堌大 する現象である．その後数年間に数多くの研究か行なわ

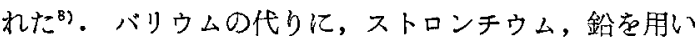
ても同様な結果が得られる。

パリウムフェライトの磁性の限界值を $B_{r}=B_{s}={ }_{B} H_{c}$ と置いて計算してみると，エネルギー積は

$$
(B \cdot H)_{\max } \fallingdotseq\left(B_{s} / 2\right)^{2} \text {. }
$$

$B_{s}$ を $4,650 \mathrm{~g}$ とすると(7) 式は, $5.4 \times 10^{6} \mathrm{~g} . \mathrm{Oe}$ と なり, Sixtus ${ }^{9}$ による $3.7 \times 10^{6} \mathrm{~g}$. Oe の值は，乙の限 界値の $2 / 3$ にも相当する大きな值である，バリウムフェ ライトは，すぐれた磁性を持ち，廉価で大量生産できる ため各方面に使われているが，温度特性が金属磁石に比 べて劣るととが欠点である。

\section{2 マンガンビスマス}

マンガンビスマスは 1904 年 Heusler ${ }^{10}$ により初めて 報告された。その後 Guillaud ${ }^{11)}$ により詳しい研究が行 なわれ，12,000 Oe の大きな抗磁力か観測された。現在， エネルギー積 $4.3 \sim 5.3 \times 10^{6} \mathrm{~g}$. Oe のものが報告されて いる ${ }^{12)}$ 。飽和磁気 $B_{s}$ ⿸ $7,800 \mathrm{~g}$, 球状粒子の充填度 $p$ を 74\%に見積ると，エネルギー積の限界值は $\left(p B_{s} / 2\right)^{2}$ $=8.3 \times 10^{6} \mathrm{~g} . \mathrm{Oe}$ となり，実験值ははとんど夷現できる 最高の值に達していると芳えられる。

マンガンビスマスはすぐれた磁性を持ちながら，原料 の高俩，製造法に難点があり，温度特性が悪いなどの点 汃ら実用化されていない。

\section{3 マンガンアルミ}

近年報告 ${ }^{13)}$ れた非常に大きな磁気異方性を持った化 合物で，マンガンビスマスと同系である．との物質の抗 磁力は，粒子径よりむしろ粉硚によって作られる反強磁 性層により粒子か汾割され，単一磁区的な振舞い星す ろのであろうと侾えられている. 現在 $40 \mu$ 程度の粒子 で残留磁気 $4,280 \mathrm{~g}, B$-抗磁力 $2,750 \mathrm{Oe}$ ，エネルギー積 $3.5 \times 10^{6} \mathrm{~g}$. Oe $の$ も方作られている。温度特性はマン ガンビスマスより良い。

\section{4 鉄, コバルト微粒子磁石}

1937 年本多博士 ${ }^{14}$ は，微粒子の表面原子の不規則が 大きな抗磁力を示すであるうと考え，シュウ酸鉄を還元 し初めて微粒子磁石を作った。1942 年 Néel ${ }^{15}$ は，鉄， コバルト蟻酸塩を低温で嗹元し，商品化に成功した。つ れら塩類を還元する方法は，粒子か球状のため形状効果 を十分利用するととができず，エネルギー積が $1.7 \times 10^{6}$ g. Oe 桎度に過ぎるった。

還元法の他に，水銀京陰極に，鉄あるいは鉄・コバト 合金定電気分解する方法がある。乙の方法で水銀中に作

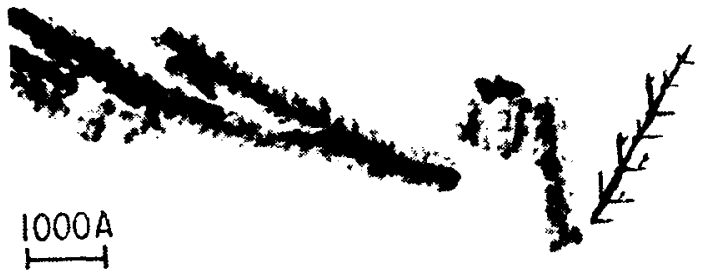

電解電流 : $0.005 \mathrm{~A}_{i} \mathrm{~cm}^{2}, B_{r} / B_{s}: 0.77, H_{c i}: 580 \mathrm{Oe}$

写真 1 電解後の粒子 ${ }^{16)}$

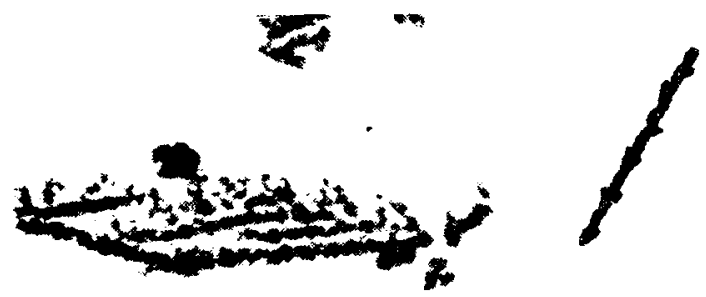

熱処理 : $150^{\circ} \mathrm{C} 15$ 分, $B_{r} / B_{s}: 0.90, H_{\mathrm{c} i}: 1510 \mathrm{Oe}$ 写真 2 熱処理をした粒子 
られる微粒子は，写真 1 で洘すような細長形の単一磁区* 粒子になっている.粒子径は電流密度と図 3 亿示すよう な関係がある。これらの樹枝状粒子を適当な温度で水銀 中熱処理を行なうと写真 2 のように，ふたたびある程度 の結晶成長が行なわれ，大きな抗磁力を示すようにな る・水銀を蒸留し金属または有機結合剂を加え磁場中成 型を施し，磁石とする。

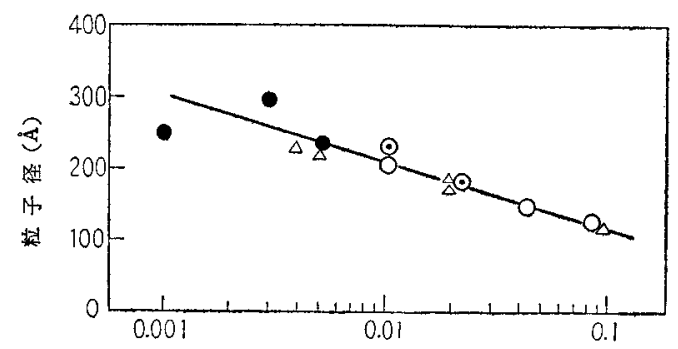

電流密度 $\left(\mathrm{A} / \mathrm{cm}^{2}\right)$
$\triangle: \mathrm{Fe}, \mathrm{O}: 29.5 \% \mathrm{Co}, \mathrm{O}: 35.5 \% \mathrm{Co}, \mathrm{O}: 40 \% \mathrm{Co}$

図 3 電流密度と精子径 ${ }^{16)}$

ての ESD 磁石の特長は，粒子の克填度を変光ると残 留磁気のみならず，抗磁力が顕著に変ることである。こ れは次のように説明される，粒子を密に充填して行く と，粒子が互に接触するため単一磁区としての性質が減 り，抗磁力が減少する. Néel ${ }^{13}$ 蛙静磁エネルギーを考 虑して, 形状異方性を有する微粒子の抗磁力 $H_{c}$ と充填 度 $p$ との関係示した。

$$
H_{c}=H_{c i}(1-p) \text {. }
$$

ここで $H_{c i}$ は $p=0$ の時, すなわち粒子が単独で存 在している埸合の抗磁力とする,ての関係はその後Kon-

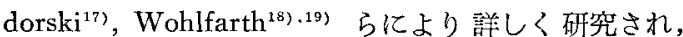
Paine 弓203,211 亿よって実験的に確められた。

との上うに, ESD 傢石は克填度を变えるととによ。 て連続的，汃容易に求劣る磁性を持った嵫石を作るこ とができるまた原料が安く，機戍加工ができる上，残 留磁気の温度係数が小さなど，数々の利点を持ってい て盛んな研究が秸けられている22),299. ESD 磁石の磁性 を他のものと此較して表2 亿上げた。

表2で明かなように，抗磁力は理墖值の数分の一に過 表 2 微粒子磁石の磁性

\begin{tabular}{|c|c|c|c|}
\hline & $B_{\gamma}(\mathrm{g})$ & ${ }_{B} H_{C}(\mathrm{Oe})$ & $\begin{array}{c}(B \cdot H) \mathrm{m} \times 10^{-6} \\
(\mathrm{~g} \cdot \mathrm{Oe})\end{array}$ \\
\hline Ba-ferrite & 4,000 & 1,930 & 3.7 \\
\hline 隄 界 值 & 4,650 & 4,650 & 5.4 \\
\hline$M n-B i$ & 4,500 & 3,500 & 5.3 \\
\hline 限＼cjkstart界 & 7,800 & 7,800 & 15 \\
\hline $\mathrm{Mn}-\mathrm{Al}$ & 4,280 & 2,750 & 3.5 \\
\hline 限 界 俻 & 6,200 & 6,200 & 9.6 \\
\hline $\mathrm{ESD}-\mathrm{Fe}$ & 9,150 & 765 & 4.3 \\
\hline 限 界 值 & 14,300 & 3,600 & 38.5 \\
\hline $\mathrm{ESD}-\mathrm{Fe} \cdot \mathrm{Co}$ & 10,800 & 980 & 6.5 \\
\hline 限 界 值 & 16,300 & 4,100 & 49.9 \\
\hline
\end{tabular}

* Elongated Single Domain, 略して ESD

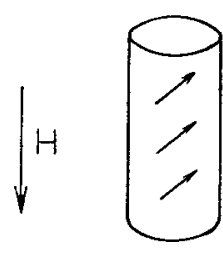

(a)

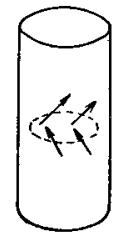

(b)
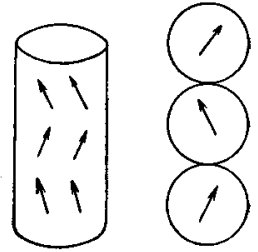

(C) (d)
a) 一禹回転模型
b) curling 模型11)
c) buckling 模型(11) d) chain-of-spheres 模型(3) 図4 磁化反転譏構

ぎない.そこで今までのスピン一斉回転模型て代って， より低いエネルギーで磁化反転が行なわれるような，い ろいろな模型が提案された（図 4).1955 年 Jacobs,

Bean $^{30}$ は，針状粒子を球状粒子の集りとして

$$
H_{c}=\pi I_{s} / 2
$$

の抗磁力を計算した。その後 Luborsky, Paine ${ }^{32)}$ は, 自由に回転できる円形磁石をスピンになぞらえ反転機構 を梌討した。その結果粒子を密につめて行くと，樹枝状 粒子の枝など，粒子の一部が互に接触し，(cross link)， その点が buckling の核となって反転が行なわれるとし， ESD 粒子の実験值ともよく一致するととを明かにした。

\section{5 析出硬化型磁石}

この磁石の抗磁力は，析出による非常に大きな内部応 力がその原因であらうと考光られていた。ところが近年 微粒子の立場からこの抗磁力を説明しようとする試みが なされた ${ }^{332,34)}$.すなわち，析出硬化型磁石を高温より磁 場中冷却すると，析出粒子が磁場方向に選択成長して形 状異方性を持つたものになる。ての粒子が前述の粒子と どうよう，大きな抗磁力を示すのであらうと考えた。る の後, Nesbitt ら $\left.{ }^{35}\right)$ は析出粒子を電子顕微鏡で観察し,

\section{とのとと確めた。}

てれら析出硬化型磁石の反転機構は，ESD 磁石と同 様に cross links を考えて説明される ${ }^{36)}$. チタンを入れ， さらに粒子を微細化した磁石（たとへば Ticonal XX) は, cross links が無くなり大きな抗磁力を示すものと考 えられている。

析出粒子の挙動孛調べることは, 粒子が単独で存在す る場合と違って幾多の困難な問題があるが，今なお盛ん な矿究が続けられている。

\section{4. 超微粒子の磁性}

前節で単一磁区粒子の抗磁力について述べたが，さら に粒子を小さくして行くと，熱ゆらぎのため抗磁力は減 少し，ある粒子径以下で零になる（図 1)。乙れは粒子 の磁気モーメントがたえず熱搌動苍行なっていて，常磁 性の舞いを呈するもので，Bean ${ }^{37)}$ はとの現象を super paramagnetism と呼んだ. 次に単軸磁気異方性を有する 
粒子について， super paramagnetic になる。臨界半恁を 計算してみょう。体積 $V$ の単一磁区粒子の磁化を反転 きせるには， $K V$ なるエネルギーの山を越さなけ扎ばな らない、粒子がだんだん小さくなると，KVの山は低く なり熱エネルギーを無視できなくなる．逆磁埸 $H$ が作 用している時のエネルギーの山は，粒子の磁気モーメン 卜を $\mu$ とすると，KV- $\mu H+\mu^{2} H^{2} / 4 K V^{38)}$ と示かれ，

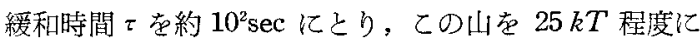
見積ると抗磁力は

$$
H_{c}=2 K V\left(1-5(k T / K V)^{1 / 2}\right) / \mu
$$

となる， $T=0^{\circ} \mathrm{K}$ に打る $H_{c}$ は (2) 式に， $T=K V /$ $25 k$ にて $H_{c}=0$ となり, super paramagnetic になる。 ニッケルについてての臨界半径を計算し, 図 5 に示し た。粒子の形が球からずれた場合には，球と同体積にな るよう長軸，短軸を決めれば良い。

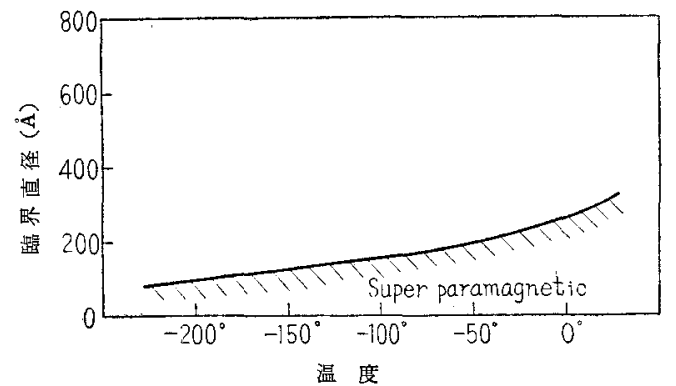

图 5 ニッケル粒子の Super paramagnetic な臨界直径

とのような粒子の磁化曲線は，粒子間の相互作月がなけ ればほぼ Langevin 函数に一致し，温度に依存する。し の温度変化は $I$ 点 $H / T$ で描けば異なった温度で得られ た曲線が一致するととから, super pavamagnetic であ るかの判定に使われる。これらの性質を利用すると，粒 子径 $r$ を決めるととができる。たとえば，Bean ら ${ }^{392}$ は 電解後の鉄アマルガムの磁化曲線之測定し, Langevin 函数の初めの部分 $I / H=4 \pi I_{s}{ }^{2} r^{3} / 9 k T$ より大きな粒子 の, 飽和付近 $I / I_{s}=1-3 k T / 4 \pi I_{s} r^{3} H$ 上り小さ柆粒子の

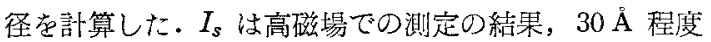
では Bulkの值と変らぬとと埌告している. 残留磁気 のある粒子と super paramagnetic な粒子とが混合して いる場合には，温度を下げながら残留磁気の增加を测定 するととにより，粒子の分布を知るととができる告る 42). これらの応用として, 銅の中に析出するコバルト微精子 の挙動 ${ }^{43)}$, 二ッケル触媒の生成過程 ${ }^{44)}$, ニッケル微粒子 のガス吸着 ${ }^{45)}$ ，岩石中の磁性物質の研究などに使われて いる。

以上，微粒子の持つ抗磁力の特晎な現象てついて，簡 単な解説を試みた。注目された交換異方性に関する破究 は，その後種々な物筫について続けられているが氵46 57)， 今のと乙ろ低温現象，あるい代館和磁気の小さなるのに
ついてであり，学問的には興味ある問題だがこれを割愛 した。その他内容の取捛，説明の不備など多いと思われ るが御容赦願いたい。

(昭 36-9-25 受理)

\section{文}

\section{献}

1) F.E. Luborsky, T.O, Paine, J. Appl. Phys. 31, 68 S (1960)

2) C. Kittel, Rev. Mod. Phys. 21, 541 (1949).

3) C. Kittel, Phys. Rev. 70, 965 (1946).

4) L. Néel, Compt. rend. 224, 1550 (1947). C. Guillaud, $J$. phys. radium 8, 347 (1947).

5) E.C. Stoner, E.P. Wohlfarth, Phil. Trans. Roy. Soc. (Lon don) A 240, 599 (1948).

6) W.H. Meiklejohn, C.P. Bean, Phys. Rev. 102, 1413 (1956).

7) J.J. Went, G.W. Rathenau, E.W. Gorter, G.W. van Oosterhout, Philips. Tech.Rev. 13, 194 (1952), F.G. Brockman, Elect. Engin. 171, 644 (1952).

8) G.W. Rathenau, J. Smit, A.L. Stuijts, Zeit. fur Physik, 133, 250 (1952), G.W. Rathenau, Rev. Mod. Phys. 25, 297 (1953), F.G. Brockman, W.G. Steneck, Philips Tech. Rev, 16, 79 (1954), A.L. Stuijts, G.W. Rathenau, G.H, Weber Philips Tech. Rev. 16, 141 (1954), K.J. Sixtus, K.J. Kronenberg, R.K. Tenzer, J. Appl. Phys. 27, 1051 (1956), I. Gordon, Ceramic Bull. 35, 173 (1956).

9) K.J. Sixtus, A.I.E.E, Mag. Conf. Proc. 142 (1955).

10) F. Heusler, Z. angew. Chem. 17, 260 (1904).

11) C. Guillaud, Thesis, Strasbourg, (1943).

12) E. Adams, M.W. Hubbard, A.M. Syeles, J. Appl. Phys. 23, 1207 (1952), E. Adams, Rev. Mod. Phys., 25, 306 (1953), J.F. Libsch, G.P. Conard, in "Relation of Properties to Microstructure", A.S.M. Cleveland, (1954).

13) A.J. Koch, P. Hokkeling, M.G. van der Steeg, K.J. Devos, J. Appl. Phys. 31, 75S (1960)

14）本多光太郎，日本金瓷学会誌，1，3 (1937).

15) L. Néel, U.S. Patent \#2,651,105 (1953).

16) F.E. Luborsky, J. Appl. Phys. 32, 171S (1961).

17) E. Kondorski, Dokl. Ak. Nauk. U.S.S.R. 70, 215 (1950), 74, 213 (1950).

18) E.P. Wohlfarth, Research, 7, SI (1954).

19) E.P. Wohlfarth, Proc. Roy. Soc. A 232, 208 (1955).

20) L.I. Mendelsohn, F.E.Luborsky, T.O. Paine, J. Appl. Phys, 26, 1274 (1955).

21) F.E. Luborsky, L.I. Mendelsohn, T.O. Raine, Am. Inst Engrs. T-91, 133 (1956).

22) R.C. Lever, E.J. Yamartino, R.B. Falk, $J$. Appl. Phys. 29, 304 (1958).

23) E.J. Yamartino, H.R. Broadley, R.C. Lever, J. Appl. Phys. 30, 144 S (1959).

24) L.I. Mendelsohn, R.S. Norman, J, Appt. Phys. 30, $142 \mathrm{~S}$ (1959).

25) R.B. Falk, G.D. Hoopev, R.J. Studders, J. Appl. Phys. 30, 132S (1959)

26) F.E. Luborsky, T.O. Paine, L.I. Mendelsohn, Powder Met. 4, 57 (1959)

27) W. Wright, Powder Met. 4, 79 (1959).

28）川口寅之輔，永倉 充，山口哲郎，田辺伊经婎，日本金属学会該， 23, 429 (1959)

29) R.B. Falk, G.D. Hooper, J. Appl. Phys. 32, $190 \mathrm{~S}$ (1961).

30) I.S. Jacobs, C.P. Bean, Phys. Rev. 100, 1060 (1955).

31) W.F. Brown, Phys. Rev. 105, 1479 (1957), E.H. Frei, S. Shtrikman, D. Treves, Phys. Rev. 106, 446 (1957).

32) F.E. Luborsky, T.O. Paine, J. Appl. Phys. 31, 66 S (1960).

33) L.Néel, Compt. rend. 225, 109 (1947).

34) C. Kittel, E.A. Nesbitt, W. Shockley, Phys. Rev. 77, 839 (1950).

35) E.A. Nesbitt, H.D. Heidenreich, $J$. Appl. Phys, 23, 352, 366 (1952)

36) T.O. Paine, F.E. Luborsky, J. Appl. Phys. 31, 78S (1960).

37) C.P.Bean, J. Appl. Phys. 26, 1381 (1955).

38) C.P. Bean, J.D. Livingston, J. Appl. Phys. 30, $120 \mathrm{~S}$ (1959). 
39) C.P. Bean, I.S. Jacobs, J. Appl. Phys. 27, 1448 (1956).

40) L. Weil, J. Chim. Phys. 51, 715 (1954).

41) L. Weil, L. Gruner, Compt. rend. 243, 1629 (1956)

42) W. Henning, E. Vogt, $Z$. Naturforsch. 12 a, 754 (1957).

43) J.J. Becker, Trans. Am. Inst. Mining. Met. Petrol. Engrs. 209, 59 (1957), 212, 138 (1957).

44) W. Heukelom, J.J. Broeder, L.L. Van Rijen, J. Chem. Phys. 51, 474 (1954).

45) P.W. Selwood, J. Am. Chem. Soc. 78, 3893 (1956), 79, 3346, 4637 (1957), 80, 1331 (1958), J. Appl. Phys. 30, 101S (1959).

46) W.H. Meiklejohn, $J$. Appl. Phys. 29, 454 (1958).

47) F.J. Darnell, J. Appl. Phys. 32, $186 \mathrm{~S}$ (1961).

48) J.S. Kouvel, C.D. Graham, J. Appl. Phys. 30, 312S (1959),
J.S. Kouvel, C.D. Graham, I.S. Jacobs, J. Phys. radium 20, 198 (1959).

49) J.S. Kouvel, $f$. Appl. Phys. 30, 313S (1959)

50) J.S. Kouvel, f. Appl. Phys. 31, $142 \mathrm{~S}$ (1960).

51) W.L. Roth, $J$. Appl. Phys. 30, 303s (1959).

52) R.H. Pry, J.S. Kouvel, E.S. Miksch, J. Appl. Phys. 31, $162 S$ (1960).

53) S.T. Lin, A.R. Kaufmann, Phys. Rev. 108, 1171 (1957).

54) J.H. Greiner, I.M. Croll, M. Sulich, J. Appl. Phys. 32, $188 \mathrm{~S}$ (1961).

55) I.S. Jacobs, J.S. Kouvel, J. Appl. Phys. 32, 274S (1961).

56) W.H. Meiklejohn, $J$. Appl. Phys. 32, 274S (1961).

57) W.H. Meiklejohn, $f$. Appl. Phys. 31, $164 \mathrm{~S}$ (1960).

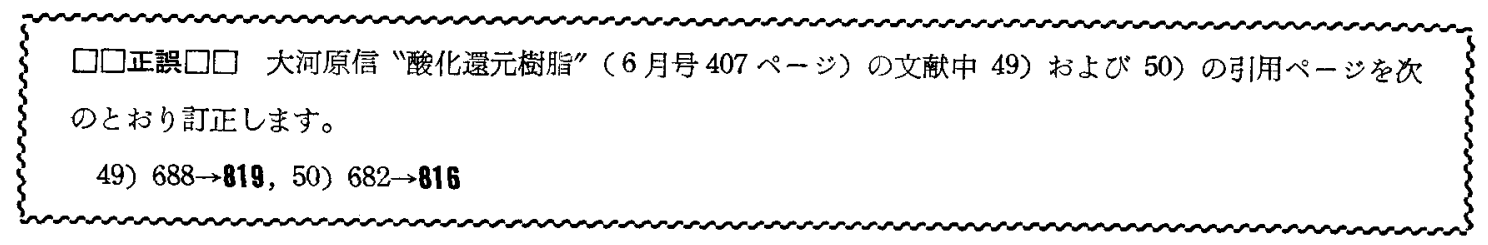

